\title{
Analysis of Chemical Composition of Underground Water
}

\author{
Ashurbekova T.N. \\ Department of Ecology and Plant Protection \\ FSBEI HPE Dagestan State Agricultural University named \\ after M. M. Dzhambulatov \\ Makhachkala city, Russian Federation \\ e-mail: ashtam72@yandex.ru \\ Isaeva N.G. \\ Department of Ecology and Plant Protection \\ FSBEI HPE Dagestan State Agricultural University \\ Department of Ecology and Plant Protection \\ Makhachkala, Russian Federation \\ e-mail: ashtam72@yandex.ru
}

\author{
Musinova E.M. \\ Department of Medical Biology \\ Dagestan State Medical University \\ Makhachkala city, Russian Federation \\ e-mail: musinova@mail.ru
}

\author{
Gadzhimusaeva Z.G. \\ Department of Ecology and Plant Protection \\ FSBEI HPE Dagestan State Agricultural University \\ Department of Ecology and Plant Protection \\ Makhachkala, Russian Federation \\ e-mail: miracle.86@mail.ru
}

\begin{abstract}
The article deals with the problem of the content of toxic elements: cadmium (Cd), lead ( $\mathrm{Pb}$ ) and arsenic (As) in artesian wells of Chervlennaya (Shelkovskiy district), Naurskaya (Naurskiy district), Petropavlovsk (Grozny district) of the Chechen Republic and their impact on the health of the population. The presence of heavy metals in the artesian wells of the studied sources can be explained by the geological structure of the territory of the Chechen Republic, which is located on the rocks of the Jurassic and Paleogene periods.
\end{abstract}

Keywords - water, heavy metals, maximum permissible concentration, oncological diseases, Chechen Republic

\section{INTRODUCTION}

In Russia, one of the main and rather acute problems is the availability of high-quality drinking water for the population.

The Chechen Republic basically does not have a shortage of water resources: both surface and underground.

On the territory of the Chechen Republic, significant groundwater resources have been identified, which are characterized by diversity in their physicochemical parameters - fresh, mineral and thermal. The reserves of these types of water are significant in terms of volume and can meet the possible demand with almost no restrictions.

One of the main sources of water supply for the population of the Chechen Republic is artesian water. This groundwater, which differ in the spectrum contained in them macro - and micronutrients. However, the artesian waters do not always meet the regulatory requirements and are safe in terms of microbiological and toxicological parameters [1-5]

The specific weight of underground water sources that do not meet the requirements of the law, due to the lack of sanitary protection zones in the Chechen Republic, is $58 \%$ according to the state report on the state and protection of the environment of the Chechen Republic.

Often, the use of artesian water for drinking supply is limited by the presence of toxic elements in them: cadmium, lead, copper, arsenic, molybdenum in concentrations exceeding the MPC [1-7].

One of the problems for these groundwaters is arsenic contamination. This problem occurs in the neighboring republics, for example, in areas of the Republic of Dagestan $[1,5]$.

In the North Caucasus Federal District, groundwater with a high content of arsenic is used for a long time by the population living in the Tersko-Kumskiy artesian basin [1-7]. In many studies, high concentrations of arsenic in artesian water have been noted for a significant number of settlements and the neighboring Republic of Dagestan [2-7].

According to the classification of the International Agency for Research on Cancer (IARC), arsenic is of the first group in danger and has a carcinogenic effect on humans. Given this, it can be assumed that prolonged use of water can lead to intoxication of the body and increase the risk of cancer with various gender characteristics [1].

It was found that even the presence of traces of arsenic in the water causes chronic poisoning, in connection with which the World Health Organization in 2006 reduced the MPC of As from $0.05 \mathrm{mg} / 1$ to $0.01 \mathrm{mg} / 1[1,8]$.

The purpose of the article was to assess the quality of water sources used for drinking water from artesian wells of st. Chervlennaya (Shelkovsky district), st. Naurskaya (Naursky district), st. Petropavlovskaya (Groznensky district) of the Chechen Republic and where we conducted studies of the incidence rate of the population. 


\section{METHODS AND MATERIALS}

The object of research was the water samples from artesian wells of st. Chervlennaya (Shelkov district), st. Naurskaya (Naursky district), st. Petropavlovsk (Grozny district).

Water analysis carried out in the laboratory of physicochemical research of the Institute of Geology of DSC RAS.

Sampling was carried out in accordance with GOST $\mathrm{R}$ 51593-2000 "Drinking water. Sampling». Chemical analysis of water samples was carried out by conventional methods. The concentrations of inorganic anions and cations-chlorides, sulfates, sodium, magnesium and calcium - were determined by the method of capillary electrophoresis on the device "Kapel-105M".

Using the atomic absorption spectrometer with electrothermal atomization "MGA-915MD" the concentrations of arsenic and heavy metals (HM): cadmium, copper, zinc, lead, iron were determined.

\section{RESULTS}

The carried out researches allowed to receive data on quality of water of artesian wells of settlements of the Chechen Republic.

Analyzing the obtained results, it can be noted that water is characterized by a rich variety of trace elements. The content of all chemical elements that belong to the trace elements necessary for normal functioning of the body and participating in metabolic processes in the body is within the MPC (Table 1).

Studies of the water samples taken for total hardness showed that the water of st. Petropavlovskaya of Grozny district is characterized by high rigidity. This impairs the organoleptic properties of water, giving it a bitter taste, and has a negative effect on the digestive organs; it can also cause various urolithiasis. According to the data "On the state of sanitary and epidemiological well-being of the population in the Chechen Republic in 2015," the average level of republican indicators for the urinary system disease is exceeded by 1.8 times in the Naursky district.

Thus, the water from this source is unsuitable for use for food purposes without pre-treatment. As can be seen from table 1, the high levels of lead, cadmium and arsenic are alarming.

According to the obtained results, it can be seen that the excess of lead and cadmium content was found in water samples from all the wells studied. The presence of these elements in water, even in small concentrations, is a signal of concern.

The main sources of heavy metals in freshwater bodies are natural: weathering of rocks, minerals, erosion processes and volcanic activity.

TABLE I. THE CONTENT OF CHEMICAL SUBSTANCES IN WATER SAMPLES FROM ARTESIAN WELLS

\begin{tabular}{|c|c|c|c|c|c|}
\hline \multirow[b]{2}{*}{ № } & \multirow[b]{2}{*}{ Components } & \multicolumn{3}{|c|}{ Content (mg/dm $\left.{ }^{3}\right)$} & \multirow{2}{*}{$\begin{array}{c}\text { MPC } \\
\left(\mathbf{m g} / \mathbf{d m}^{3}\right)\end{array}$} \\
\hline & & $\begin{array}{c}\text { Shelkovskoy District } \\
\text { stanitsa of Chervlyonnaya }\end{array}$ & $\begin{array}{c}\text { District } \\
\text { stanitsa of Naurskaya }\end{array}$ & $\begin{array}{c}\text { Groznensky District } \\
\text { stanitsa of Petropavlovskaya }\end{array}$ & \\
\hline 1 & $\mathrm{Na}^{+}, \mathrm{mg} / \mathrm{L}$ & $169.1 \pm 12.3$ & $50.1 \pm 1.22$ & $34.1 \pm 1.9$ & \\
\hline 2 & $\mathrm{~K}^{+}, \mathrm{mg} / \mathrm{L}$ & $4.9 \pm 1.6$ & $2.9 \pm 01.1$ & $4.4 \pm 1.3$ & \\
\hline 3 & $\mathrm{Mg}^{2+}, \mathrm{mg} / \mathrm{L}$ & $1.0 \pm 0.2$ & $21.1 \pm 1.27$ & $34.1 \pm 2.24$ & \\
\hline 4 & $\mathrm{Ca}^{2+}, \mathrm{mg} / \mathrm{L}$ & $8.8 \pm 1.0$ & $50.1 \pm 5.8$ & $89.1 \pm 10.0$ & \\
\hline 5 & $\mathrm{Fe}, \mathrm{mg} / \mathrm{L}$ & $0.012 \pm 0.001$ & $0.049 \pm 0.012$ & $0.100 \pm 0.030$ & 0.3 \\
\hline 6 & $\mathrm{Co}^{2+}, \mathrm{mg} / \mathrm{L}$ & $0.013 \pm 0.002$ & $0.009 \pm 0.003$ & $0.009 \pm 0.001$ & 1.0 \\
\hline 7 & $\mathrm{Zn}^{2+}, \mathrm{mg} / \mathrm{L}$ & $0.001 \pm 0.001$ & $0.002 \pm 0.001$ & $0.003 \pm 0.001$ & 5.0 \\
\hline 8 & $\mathrm{Sr}^{2+}, \mathrm{mg} / \mathrm{L}$ & $0.30 \pm 0.11$ & $0.40 \pm 0.12$ & $0.63 \pm 0.11$ & 7.0 \\
\hline 9 & $\mathrm{~F}^{-}, \mathrm{mg} / \mathrm{L}$ & $0.3 \pm 0.05$ & $0.1 \pm 0.07$ & $0.2 \pm 0.05$ & 1.5 \\
\hline 10 & $\mathrm{Cl}^{-}, \mathrm{mg} / \mathrm{L}$ & $37.9 \pm 11.5$ & $27.1 \pm 11.7$ & $68.9 \pm 13.3$ & 350 \\
\hline 11 & $\mathrm{NO}_{3}^{-}, \mathrm{M \Gamma} / \mathrm{J} / \mathrm{mg} / \mathrm{L}$ & $0.07 \pm 0.01$ & $0.06 \pm 0.01$ & $0.12 \pm 0.09$ & 45 \\
\hline 12 & $\mathrm{SO}_{4}^{2-}, \mathrm{mg} / \mathrm{L}$ & $130.7 \pm 13.5$ & $137.1 \pm 30.1$ & $122.9 \pm 28.2$ & 500 \\
\hline 13 & $\mathrm{HCO}_{3}^{-}, \mathrm{mg} / \mathrm{L}$ & $323.1 \pm 14.1$ & $234.1 \pm 14.5$ & $234.1 \pm 44.0$ & - \\
\hline 14 & Mineralization, $\mathrm{mg} / \mathrm{L}$ & $789.1 \pm 56.0$ & $509.2 \pm 58.6$ & $678.3 \pm 234.2$ & 1000 \\
\hline 15 & Hardness, mg-eq/L & $1.7 \pm 0.1$ & $4.7 \pm 1.6$ & $7.8 \pm 1.25$ & 7.0 \\
\hline 16 & $\mathrm{pH}$ & $7.4 \pm 4.2$ & $7.3 \pm 3.7$ & $7.1 \pm 4.5$ & $6-9$ \\
\hline 17 & $\mathrm{~Pb}, \mathrm{mg} / \mathrm{L}$ & $0.05 \pm 0.001$ & $0.04 \pm 0.001$ & $0.05 \pm 0.001$ & 0.01 \\
\hline 18 & $\mathrm{Cd}, \mathrm{mg} / \mathrm{L}$ & $0.005 \pm 0.0001$ & $0.007 \pm 0.0001$ & $0.009 \pm 0.0002$ & 0.001 \\
\hline 19 & $\mathrm{As}, \mathrm{mg} / \mathrm{L}$ & $0.048 \pm 0.001$ & $0.015 \pm 0.002$ & $0.062 \pm 0.003$ & 0.01 \\
\hline
\end{tabular}

The natural sources of lead in surface water are the processes of dissolution of endogenous and exogenous minerals (galena, cerussite, etc.).

The man-made source is motor transport, since it is near highways that high concentrations of cadmium and lead are observed, since the compounds of this element are part of diesel fuel and gasoline as antiknock agents.

We exclude other man-made sources, such as mining and processing of mineral resources, since such work is not carried out on the territory of these regions of the Chechen Republic. 
In all the artesian well water samples studied, the arsenic content exceeded the permissible concentration established by the regulatory documents (GOST 2874-82, SanPiN 2.1.4.1074-01), in 1.5-6.2 times.

With prolonged exposure to arsenic compounds irreversible processes begin in the body. The body begins to suffer from anemia; skin emaciation, peeling, ulceration; the muscles of the arms and legs gradually atrophy, malignant changes occur. The toxic effect of arsenic is due to the blocking of sulfhydryl groups and other biologically active substances. Exposure to As can cause cancer of the lungs, skin, liver, stomach, as well as nerve and other disorders [10$16]$.

A set of conditions is considered as the reason for the intake of arsenic into groundwater: geochemical features, the presence of arsenic ions forming soluble complexes with metals in rocks, and anthropogenic factors [9]. A number of researchers suggest that, due to the high mobility of arsenic salts at high temperatures, this element migrates in the composition of juvenile waters to the surface of the earth from magma chambers [9].

The content of arsenic in drinking water is also determined by the nature of the underlying rocks. In some geological formations, arsenopyrite occurs, which is a source of arsenic in fresh water and leads to an increase in its concentration in the region.

The entry of toxic elements such as lead, cadmium and arsenic into the body, even in minute quantities, leads to severe pathological phenomena in the body. And the constant use of water containing these ecotoxicants has an adverse effect on the health of the entire population [4, 8-9].

Lead, cadmium and arsenic have a cumulative and toxic effect and are carcinogenic.

However, the fact that one of the most important factors affecting the health of the population is the quality of drinking water and the causal relationship of the water factor is considered to be reasoned [4, 8-16].

It is believed that the water from these sources is unsuitable for drinking without pre-treatment.

Thus, studies have shown that the drinking water supplied by the population of the above-mentioned districts of the Chechen Republic, supplied from these water sources and wells, is one of the possible ways for the entry of toxic elements, i.e., it can be a risk factor.

The reason for the presence of heavy metals in the water of these areas is a natural factor.

Similarity reveals in the structure of mortality in the Chechen Republic and the Russian Federation as a whole (as a percentage): the leading causes of mortality in the Chechen Republic and in the Russian Federation as a whole are circulatory system diseases (the Chechen Republic - 57\%, the Russian Federation - 58\%) and malignant neoplasms (the Chechen Republic - 12\%, the Russian Federation - 14\%) (Table 2).
TABLE II. MORTAlity StRUCtURE OF THE CHECHEN RePUbliC POPULATION

\begin{tabular}{|c|c|c|c|}
\hline № & Causes of death & $\begin{array}{c}\text { The Russian } \\
\text { Federation }\end{array}$ & $\begin{array}{c}\text { The Chechen } \\
\text { Republic }\end{array}$ \\
\hline 1 & $\begin{array}{c}\text { Diseases of the } \\
\text { circulatory system }\end{array}$ & $58 \%$ & $57 \%$ \\
\hline 2 & Neoplastic disease & $14 \%$ & $12 \%$ \\
\hline
\end{tabular}

Similarities reveals in the structure of mortality in the Chechen Republic and the Russian Federation as a whole (as a percentage) - this is evident from table 2. Comparing the figures in table 2 , it can be noted that the percentage of mortality in the Chechen Republic is almost equal to this indicator in the Russian Federation.

As an example, the same areas of the republic were considered, where the problem is with water quality, taking into account that some authors attribute the growth of malignant neoplasms among the population to the quality of drinking water $[2,7]$.

Analyzing the situation in these areas, they can be characterized as areas with different rates of overall cancer incidence in the Shelkovsky district (47.49); Grozny district (64.24) and Naursky district (83.41).

Of the regions presented, the highest level of overall cancer incidence is characteristic of the Naursky district.

The leading localizations in the structure of cancer morbidity of the population of Grozny rural area are trachea, bronchi, lungs (17.42\%); skin (14.23\%); lacteal gland (12.89\%); reproductive system (10.52\%); stomach $(8.61 \%)$.

Leading localizations in the structure of cancer incidence in the population of the Shelkovsky district are skin (19.59\%); lacteal gland $(17.18 \%)$; the reproductive system $(15.12 \%)$; oncology of the rectum, rectosigmoid compound, anus $(6.19 \%)$ and the trachea, bronchi, lungs $(4.81 \%)$.

Leading localizations in the structure of cancer rates in the Naursky district are the trachea, bronchi, and lungs $(8.44 \%)$; skin $(15.61 \%)$; lacteal gland $(16.46 \%)$; the reproductive system $(15.82 \%)$ and stomach $(7.32 \%)$.

Thus, cancer morbidity and mortality is one of the most indicative medical trends of ill-being in this region. One of the reasons for the development of this disease is the ingestion of carcinogenic substances and toxic elements, which have a carcinogenic effect on the body, the most dangerous of which are lead, cadmium and arsenic.

Based on the above, one can see the dependence between cancer diseases in the 3 studied areas and the ecological situation in these areas, i.e., with the quality of drinking water.

\section{CONCLUSION}

As a result of our research on the water of artesian wells of the Chechen Republic, it was found that the main elements of pollution in these waters are lead, cadmium and arsenic compounds, which have a cumulative and toxic effect.

Prolonged exposure to inorganic arsenic when drinking polluted water, consuming food, prepared with such water, or 
eating agricultural crops irrigated with water rich in arsenic, can lead to chronic poisoning with this chemical element.

Analyzing the high percentage of cancer incidence in the studied areas and the high level of potentially hazardous to human health elements: cadmium, lead and arsenic in the drinking water of this area, we concluded that one of the factors for the growth of cancer is drinking water quality.

Noting that water, in which an increased content of toxic elements is detected, can serve as a risk factor, it is recommended that water from these sources be used for drinking purposes only after preliminary treatment.

\section{References}

[1] T.O. Abdulmutalimova, B.A. Revich, "Groundwater, drinking water, arsenic pollution, North Daghestan", South of Russia: ecology, development, 2012, vol. 7, no 2, pp. 81-86.

[2] T.N. Ashurbekova, Z.G. Gadzhimusaeva, L.L. Sherifova, "Water quality analysis of the Republic of Dagestan and the environmental situation", International Research Journal, no. 45, 2016, pp.12-13.

[3] T.S. Astarkhanova, T.N. Ashurbekova, L.B. Bagavdinova, "Arsenic water pollution in the Republic of Dagestan", Makhachkala, 2013, pp. 197-200. [Collection of materials of the All-Russian scientific-practical conference on agricultural modernization, 2013]

[4] T.N. Ashurbekova, "Comprehensive environmentalgeographical analysis of the incidence of neoplasms of the population of the Chechen Republic", Problems of regional environmental management, no.1, 2017, pp. 13-19.

[5] M.K. Kurbanov, Geoecological problems of development and protection of groundwater resources of the Eastern Caucasus, Proceedings of the Institute of Geology RAS, no. 49, Makhachkala, 2003.

[6] D.I. Kadiev, Sh.G. Abdurakhmanov, Sh.M. Samudov, A.A. Gadzhiev, "Analysis of the quality of drinking water in the
Kizilyurtovskiy district of the Republic of Dagestan", South of Russia: ecology, development, Vol. 10, no.1, pp. 13-25.

[7] G.G. Onishchenko, Yu.A. Rakhmanin, F.V. Karmazinov, V.A. Grachev, E.D. Nefedova, Benchmarking. The role of drinking water quality, monography. St. Petersburg: Novyy zhurnal, 2010 , p. 463

[8] S.S. Chuburkova, A.N. Murzayeva, N.G. Isaeva, R.D Ataeva., Z.A. Azizova, "Analysis of water quality in the village of Terekli-Mekteb of Nogayskiy District of the Republic of Dagestan", Makhachkala, 2017, pp. 236-239. [Proc. of the scientific-practical conference on Ecological problems of agriculture and scientific and practical ways to solve them].

[9] J.D. Ayotte, Z. Szabo, M.J. Focazio, S.M. Eberts, "Effects of human-induced alteration of groundwater flow on concentrations of naturallyoccurring trace elements at watersupply wells", Applied geochemistry, 2011, vol. 26, no. 5, pp 747-762.

[10] D. Sutorova, J. Adamkov, J. Fundarek, "Psychologicke nalezy u hutnikov pracujucich v dihodobej expozicii menganom", Neurol. a neurochir, 1986, vol. 49, No. 4, pp. 236-241.

[11] R.F. Hertel, "Sources of exposure and biological effects of chromium", Environ. Carcinogens Selec. Meth. Anal. Lyon., 1986, vol. 8, pp. 63-77.

[12] D. E Lilienfeld, "Arsenic, geographical isolates, environmental epidemiololgy, and arteriosclerosis", Arteriosclerosis, 1988, Vol. 8, No. 5, pp. 449-451.

[13] M.I. Fernández, J.F. López, B. Vivaldi, F. Coz, "Long-term impact of arsenic in drinking water on bladder cancer health care and mortality rates 20 years after end of exposure", The Journal of Urology, Jan. 2012

[14] L.M. Del Razo, G.G. García-Vargas, O.L. Valenzuela, E.H. Castellanos, L.C. Sánchez-Peña, J.M. Currier et al, "Exposure to arsenic in drinking water is associated with increased prevalence of diabetes: a cross-sectional study in the Zimapán and Lagunera regions in Mexico", Environmental health: a global access science source, Aug. 2011

[15] E.M. Alissa, G.A. Ferns, "Heavy Metal Poisoning and Cardiovascular Disease", Journal of Toxicology, Sept. 2011

[16] M.S. Bloom, E.F. Fitzgerald, K. Kim, I. Neamtiu, E.S. Gurzau, "Spontaneous pregnancy loss in humans and exposure to arsenic in drinking water", International Journal of Hygiene and Environmental Health, vol. 213(6), pp. 401-413, 2010. 